\title{
Intertextuality in the News Articles on the Security Situation in Iraq
}

\section{Instructor Huda Hadi Khalil}

Baghdad University

\section{College of Education for Women /Department of English \\ Email: hudahadi7@yahoo.com}

\begin{abstract}
:
Intertextuality refers to the relationship with which texts are interwoven with each other. It is used to describe the range of ways in which texts make reference to other texts. Recently, mass media and modern technology has become a global issue and started influencing every individual. The information presented in the mass media affects the way people think. Thus, both form and content of mass media are of major importance. News article reporters need to be creative in their language and, at the same time, refer to facts and use common forms of language. Intertextuality is very common among mass media reporters because it is a powerful tool that serves their purposes. The present paper aims at analyzing the reasons which motivates reporters of the news articles on the security situation in Iraq to resort to intertextuality. The period between April and July 1214 is one in which the security situation in Iraq has been in turmoil. Therefore, twelve news articles belonging to the period above have been downloaded from the internet and analyzed carefully. The model adopted in the analysis is that of Bazerman (2004:5) for being a unified comprehensive scheme which covers all the types of techniques presented by other linguists. The analysis has revealed a heavy use of intertextuality in these news articles with particular focus on particular techniques rather than the others for certain reasons that serve the reporters' purposes.
\end{abstract}




\section{Section One}

\section{Introduction}

No text is an island is an expression most likely familiar to anyone specialized in literature. The expression basically means that every text interacts with other texts, even though readers may not always even recognize the references every time they occur. This linguistic phenomenon is known as intertextuality which refers to the relationship through which texts are interwoven with each other. It is used to describe the range of ways in which texts make reference to other texts; it is a relation a text has with other texts. It is claimed that almost every word people use has already been seen, heard or written before. These intertextual references, however, often convey some sort of significance and purpose in their new context, whether it is to emphasize the meaning or importance of a specific occurrence, to invoke comparison between the two texts, or even to create humor by, for example, ridiculing the original text. The expression no text is an island itself includes an intertextual reference to a well-known quote from the poet John Donne (1624), "No Man Is an Island" (http://www.online-literature.com/donne/409/).

Nowadays, information processes have acquired a global character. Due to modern technologies, mass media, being one of the most common ways of influencing people, have an impact not only on all spheres of human society but also on every individual. Information and the way it is transmitted can shape the way people think and form their views. Therefore both the form and the content of mass media texts are essential.

While writing their news articles, reporters face a controversial problem - they need to be creative and unique along with relying on and referring to facts and using the common stock of language. Sometimes the reporters, who want to sound subjective, employ other people's words without drawing the readers' attention to their origin. At other times, the reporters who pursue different objectives, point to the source of information they use.

Since in media discourse the issue of intertextuality is very popular among reporters, who widely use this powerful tool for suiting their own 
purposes, the present paper aims at the analysis of reasons motivating reporters of news articles tackling the security situation in Iraq to resort to intertextuality. The analysis depends on careful examination of the set of intertextuality techniques that the reporters have relied on in these articles.

The security situation in Iraq has witnessed many periods of serious escalation. Among these periods is the one between April and July 2014. The aim is to find out how the reporters employ intertextuality to inform the world about the security situation in Iraq in one of its critical periods. Thus, twelve news articles which belong to this period have been downloaded from the internet and subjected to careful analysis.

Bazerman's (2004: 5) model of intertextuality has been adopted in particular for a set of reasons: it is detailed, clear, comprehensive, and it represents an organized collection of all the techniques which the other linguists have presented. It is really a unified comprehensive scheme which covers all the types of techniques presented by other linguists.

\section{Section Two}

\section{What Intertextuality Is}

Intertextuality (henceforth IN) has been a prominent issue in the critical analysis of texts. However, its various interpretations have made it a complex term. Etymologically speaking, IN means a text among texts. For structuralists a text has always been considered a closed structure, a compact whole, having sovereignty and distinct boundaries. Interpretation for such a structure is considered to be stable and author-centered (Panigrahi, 2013: 251).

IN is one of the common practices which may contribute in reshaping identities and attitudes. It derives its meaning from shared knowledge between the users and the readers that enable the readers to grasp the covert meaning of a particular text (Cook, 2001: 220). Goddard (2007: 69) identifies that it is relevant to the way one text can point to or 
base itself on another text. IN, however, is not an intended reference by an author to another text; it is the very condition of signification, of meaning, in literary texts and indeed all languages (Allen, 2003:82).

Although IN is one of the central concepts in literary theory, it is a term more difficult to define than one would imagine. As a term, it was first coined by Julia Kristeva in the late 1960s, but the theory of IN has its origins in the groundbreaking work of the Swiss linguist Saussure in the early twentieth-century. IN, therefore, emerges from theories that emphasize the systematic features of language in establishing the relational nature of meaning and texts, and also from theories which are concerned with language use within specific social situations (Allen, 2000: 2-3).

Montgomery et al. (2007: 161) describe IN as emphasizing "the idea that texts are not unique, isolated objects" and that they are constructed out of numerous other texts which may be both known and unknown.

According to the work of Julia Kristeva, Bazerman (2004:84) defines IN as the "relation each text has to the texts surrounding it". He explains that "intertextuality, for Kristeva, is a mechanism whereby we write ourselves into the social text, and thereby the social text writes us" (ibid: 2).

IN can also be described as the capacity of a text to evoke other texts available in the culture. A text may evoke other texts at different levels of IN, and through different techniques of intertextual representation (ibid: 86-89).

It is possible to say that IN is not a matter of decorating a text with other texts and its application in a text does not bear any underlying meaning. It is not used by a writer only to illuminate his/her text without bearing a certain meaning. The use of IN has its own meaning in the text though the meaning itself is not consciously construed by the writer. 
Moreover, the reason that IN is there because it is a common practice of a certain text indicates that there exists a meaning which is, by itself, a common practice. Therefore, the meaning that emerges from the use of IN in a text should be perceived differently from the lexical meaning of words (Pulungan, 2010: 139).

\section{Section Three The Classification of IN}

Different theorists approach, discuss and develop IN from different perspectives and classify it into different categories. The following are the most common classifications.

\subsection{Macro- IN and Micro- IN}

Culler (1981) (as cited in Liu and Le (2013: 12) talked about two types of relations: macro-intertextuality and micro- intertextuality. In a broad sense, the whole world is considered a text. The relationship between a text and its signifying practice is reciprocally referential. In a narrow sense, IN refers to the relationship between a given text and other texts existing in a given text.

\subsection{Strong IN and Weak IN}

As far as the French theorist Laurent Jenny ((1982) cited in Liu and Le (2013: 12)) is concerned, IN falls into strong IN and weak IN. The former refers to the obviously shown reference relation between a given text and other texts such as quotations, plagiarism and piercing, while the latter indicates that a given text implies something that induces semantic associations of other texts, such as similar opinions, topic ideas, genres, etc.

\subsection{Manifest IN and Constitutive IN}

In manifest IN, other texts are explicitly presented in the text under analysis; they are manifestly marked or cued by features on the surface of the text, such as quotation marks (Fairclough, 1992: 104). The constitutive IN refers to the complex relation of genres or discourse types' convention. 
It is the configuration of discourse conventions when the text is produced (ibid: 104-105).

\subsection{Specific IN and Generic IN}

According to Xin (2000, 6-14), specific IN refers to a given text which contains others' discourses with concrete sources identified. Such IN entails strong IN, manifest IN and the intertextual relation triggered by quotation from others' discourse. Generic IN refers to the integration of different styles, registers or genres. Bhatia (2010: 32) has used the terms explicit and implicit IN to refer to these types of IN.

Although the scholars do not interpret IN completely in the same way, still they share some common points. It seems that the above strong, manifest or specific IN refers to the obviously shown, surface or concrete IN relation, while weak, constitutive or generic IN means semantic associations of ideas, genres, registers, etc.

In fact, it is hard to get a unanimous idea about IN. However, the paper is limited to tackling IN in the news articles on the security situation in Iraq (henceforth NASSI) in the narrow sense, or micro-IN. It focuses on the intertextual relation with the concrete sources or the obviously shown and surface intertextual relations which have been identified by Xin (2000: 6- 14).

\section{Section Four}

\section{The Levels and Techniques of IN}

In the present paper, Bazerman's (2004) perspective on IN is employed as the point of departure to analyze the intertextual practices of each sample text. For the purposes of analysis, Bazerman (ibid: 3-4) distinguishes the different levels at which a text invokes another text and relies on the other text as a resource. He identifies six levels of IN that emerge in a text as follows: 
1. The text may refer to other texts 'as a source of meanings to be used at face value.' It happens when a particular text takes statements from another source as authoritative and then repeats that authoritative information or statement in the new text. For example, in a U.S. Supreme Court decision, passages from the U.S. Constitution can be cited as authoritative elements, though the application to the case at hand may be argued.

2. The text may refer to "explicit social dramas of prior texts engaged in discussion.' For example, a newspaper report may tell the viewpoints of opponents in a political struggle which, in fact, reoccurs in the newspaper story and the opponents may be using the newspapers to get their view across as part of that struggle; nonetheless, the newspaper brings the statements side by side in a direct confrontation.

3. A text may also explicitly use statements from other texts as background, support, and contrast. For example, in a particular paper, a researcher may use figures from an encyclopedia, newspaper reports, or use quotations from a work of literature to support an analysis.

4. The text, less explicitly, may rely on beliefs, issues, ideas, or statements generally circulated and may be familiar to the readers as common knowledge. An example is when a newspaper article tries to discuss how to answer the young adolescents' social, emotional, and physical needs. The discussion indirectly relies on common beliefs about the difficult transitions of adolescents as well as fictional, journalistically embellished, and honestly factual accounts of troubled youth and youth violence.

5. A text may implicitly use recognizable kinds of language, phrasing, and genres to evoke particular social worlds where such language and language forms are used as an attempt to identify that text as part of those worlds. 
The present paper, for example, tries to use language recognizably associated with the university research and textbooks.

6. A text may rely on the available resources of language without calling particular attention to the intertext through the use of language and language forms. For example, a news article, which discusses the youth's needs, may rely on the familiarity with the idiomatic phrase 'feeling the squeeze' which had its origins in underworld language and then worked its way into sports and business.

Depending on these levels of IN, Bazerman (ibid: 5) has recognized certain techniques that represent the words and utterances of others. Thus, starting with the most explicit, the techniques of IN are as follows:

1. Direct Quotation: this technique is identified by the use of quotation marks, block indentation, italics, or other typographic elements that set certain excerpt apart from the other words of the text. Although the second author should be committed to the exact words of the original author, he/she has control over exactly which words will be quoted, the points at which the quote will be cut out, and the context it will be used in

2. Indirect Quotation: it depends on specifying a source and then attempting to reduce its meaning through the use of words that reflect the second author's understanding and interpretation of the original text. This technique filters the meaning through the second author's words and attitude allowing the meanings to be more thoroughly infused with the second author's purpose. When the text producer resorts to indirect quotation to retell what someone else has said, quotation marks disappear, tense and deictic change to suit the writer's style and readers can never be sure whether the words belong to the original speaker or not. 
3. Mentioning a person, document or statements: it depends on the reader's familiarity with the original text and what it says. The second author has the opportunity to imply what he/she wants about the original text or to rely on general beliefs about the original text without having to substantiate them since no details of meaning are specified.

\section{Comment on or Evaluate a Statement, Text, or Otherwise Invoked} Voice: it happens when, for example, a reporter of a news article accepts a fact as truthful and definitive although it has been criticized. He/she may also see the original concept undermined and pass judgments on some issues.

\section{Using Recognizable Phrasing, Terminology Associated with Specific} People or Groups of People or Particular Documents: a researcher may criticize middle grade math and science education by the phrase "an intellectual wasteland" that recalls Newton Minnow's famous statement of the sixties calling television "a vast intellectual wasteland." This phrase evokes major public controversy over educational issues and suggests that middle school education has no more value than television as an educational tool.

\section{Using Language and Forms That Seem to Echo Certain Ways of} Communication, Discussions among Other People, and Types of Documents. Under this heading, genres, kinds of vocabulary (or register), stock phrases, or patterns of expression of this sort may all be included. For example, a researcher who writes about controversial educational points uses a form of language that brings us through worlds of educational planning, political movements, statistical evaluation, and policy controversy. 
These six techniques have been discussed in different ways by different linguists. In the present paper, the analysis of IN in the NASSIs has been done depending on Bazreman's (2004) presentation of techniques since this presentation is detailed, clear and comprehensive at the same time. It is really an organized collection of all the techniques which the other linguists have presented. Bazerman (Ibid) has gathered all the techniques, that the other linguists have talked about, in a unified comprehensive scheme which covers all the types of techniques presented by others.

\section{Section Five}

\section{The Analysis of IN Techniques in the NASSI}

The present paper aims at investigating IN in news articles the topic of which has something to do with the security situation in Iraq. This investigation has been done in order to find out the purposes that the use of IN serves in such news articles. It goes beyond dispute that the security situation in Iraq has witnessed serious escalation in the period between April and July, 2014. The security events in Iraq have topped the headlines in the media and reporters have done everything possible to win the competition like in reporting what has been going on in Iraq. For this purpose, the reporters have mainly relied on some linguistic tools one of which is IN. Thus, IN has been carefully investigated and analyzed in twelve NASSIs in that period in particular. The articles have been downloaded from the internet from different broad casting corporations and newspapers.

Concerning the frequency of occurrence of IN instances, there have been 246 instances of IN in the 12 articles analyzed. These instances have been investigate and pointed out depending on the six techniques of Bazerman (2004: 5). The following table shows the distribution of the 246 instances of IN among the six techniques: 


\begin{tabular}{|c|c|c|c|c|c|c|}
\hline $\begin{array}{l}\text { No. of } \\
\text { News } \\
\text { Article }\end{array}$ & $\begin{array}{c}\text { Direct } \\
\text { Quotation }\end{array}$ & $\begin{array}{c}\text { Indirect } \\
\text { Quotation }\end{array}$ & $\begin{array}{l}\text { Mentioning } \\
\text { a person, } \\
\text { document } \\
\text { or } \\
\text { statements }\end{array}$ & $\begin{array}{c}\text { Comment } \\
\text { on or } \\
\text { Evaluate a } \\
\text { Statement, } \\
\text { Text, or } \\
\text { Otherwise } \\
\text { Invoked } \\
\text { Voice }\end{array}$ & $\begin{array}{c}\text { Using } \\
\text { Recognizable } \\
\text { Phrasing, } \\
\text { Terminology } \\
\text { Associated } \\
\text { with Specific } \\
\text { People or } \\
\text { Groups of } \\
\text { People or } \\
\text { Particular } \\
\text { Documents }\end{array}$ & $\begin{array}{l}\text { Using Language } \\
\text { and Forms That } \\
\text { Seem to Echo } \\
\text { Certain Ways of } \\
\text { Communication, } \\
\text { Discussions } \\
\text { among Other } \\
\text { People, and } \\
\text { Types of } \\
\text { Documents. }\end{array}$ \\
\hline 1 & 1 & 5 & 1 & 1 & & 12 \\
\hline 2 & 1 & 12 & 3 & 2 & & 23 \\
\hline 3 & 1 & 3 & & & & 2 \\
\hline 4 & 6 & 8 & 2 & & & 4 \\
\hline 5 & 3 & 7 & & 3 & & 18 \\
\hline 6 & 2 & 6 & & & 1 & 1 \\
\hline 7 & 6 & 20 & & 3 & & 7 \\
\hline 8 & & 3 & & & & 8 \\
\hline 9 & & & 1 & & & 14 \\
\hline 10 & & & 3 & & & 7 \\
\hline 11 & & & & & & 17 \\
\hline 12 & 3 & 2 & 6 & & & 18 \\
\hline $\begin{array}{c}\text { Total } \\
\text { Number }\end{array}$ & 23 & 66 & 16 & 9 & 1 & 131 \\
\hline Average & $9 \%$ & $27 \%$ & $6.5 \%$ & $4 \%$ & $0.5 \%$ & $53 \%$ \\
\hline
\end{tabular}

Table (1): The Frequency of Occurrence of Each Technique in the Twelve Articles 
The table above reveals the following points:

1. It is clear that the technique which has the highest frequency of occurrence is using language and forms that seem to echo certain ways of communication, discussions among other people, and types of documents; that is technique number six. Among the 246 instances of IN, 131 are related to the sixth technique forming a percentage of 53\%. Generally speaking, in this technique, the reporter can use genre, kinds of vocabulary (or register), stock phrases, or patterns of expression which seem to associate with a particular type of texts. The reporters of the twelve NASSIs have, in particular, used kinds of vocabulary that can be divided into the following categories:

a) Religious in general,

b) Religious communities,

c) National communities,

d) Geographical terminology,

e) Military terminology.

The following table shows the frequency of occurrence of each category:

\begin{tabular}{|l|l|}
\hline The Category & Frequency of Occurrence \\
\hline Religious in General & 3 \\
\hline Religious Communities & 77 \\
\hline National Communities & 16 \\
\hline Geographical Terminology & 20 \\
\hline Military Terminology & 52 \\
\hline Total Number & $\mathbf{1 3 1}$ \\
\hline
\end{tabular}

Table (2): The Frequency of Occurrence of Each Vocabulary Category

According to the table above, the vocabulary which refers to the religious communities has occurred more than the other categories. Of the 77 instances of this category, 76 have been devoted to two words only 
(namely Sunni and Shiite) and one instance for the phrase religious communities itself which the reporter has used to remind the readers of the fabricated civil war of 2006-2008 as shown in the following extract:

However, political divisions, in combination with a weak state and high unemployment, make Iraq one of the most unstable countries in the Middle East. The country remains deeply scarred by the brutal civil war (2006-08) that has poisoned relations between Iraq's religious communities for generations to come.

(http://middleeast.about.com/od/ira1/tp/Current-Situation-InIraq.htm)

The following extract is an example of the heavy use of the two words Sunni and Shiite which have occurred in every article with no exception:

The bodies were found in a farming area less than a mile from a road. Although no one has said whether the men who were killed were Sunni or Shiite, many in the area assume they were Sunnis. The region is majority Shiite with a significant Sunni population.

In another incident in Hillah on June 23, about 70 Sunni prisoners ... were killed in apparent retaliation for the killing of 1,700 people, largely Shiites, whom the Islamic State in Iraq and Syria boasted they had killed in Tikrit....

In a separate incident on June 18 in Diyala Province, 44 Sunni prisoners were killed in Baquba, the provincial capital. (http://www.nytimes.com/2014/07/10/world/middleeast/inapparent-mass-killing-bodies-found-in-region-south-of Baghdad.)

It is worth mentioning here that the two words of Sunni and Shiite are mostly avoided in the real Iraqi community, especially publically and among educated people. Moreover, they are almost a taboo kind of words according to a considerable number of Iraqis since they give hints to 
difference and discrimination which are the main reasons of the miseries of the Iraqi people.

However, this is not the case in the foreign NASSI in which there is a sort of insistence on the use of these two words on purpose. Compared with this heavy use of the two words, there is one time in which the word nationalists has been used to refer to a group of Iraqis who call for the unity among the different Iraqi religious communities. Unfortunately, however, the only occurrence of the word nationalists is almost nothing when compared with the 76 instances of the other two words.

The reporters have manipulated these words in a way that shows the Iraqi community as a sectarian and traditionally tribal community. The reporters have described one Iraqi religious community as a supporter of terrorism and the other community as an oppressor one that takes away the rights of others. The following extracts are pieces of evidence for these false alleged claims:

Fighters from ISIL - an al Qaeda offshoot which says all Shi'ites are heretics who should be killed - have been assisted in their advance by other, more moderate Sunni armed groups who share their view that Sunnis have been persecuted under

(http://www.reuters.com/article/2014/06/26/ MALIKI UNDER PRESSUREUSKBNOF10TF20140626)

Al Qaeda-linked Sunni extremists continue with regular attacks against government targets and Shiites. The potential for economic development is huge, but violence remains endemic....

(http://middleeast.about.com/od/iral/tp/Current-Situation-InIraq.htm)

The violence is spiking again. April 2013 was the deadliest month since 2008, marked with clashes between Sunni antigovernment protesters and security forces, and bomb attacks 
against Shiites and government targets carried out by the Iraqi branch of Al Qaeda organization....

(http://middleeast.about.com/od/iral/tp/SectarianTension-InIraq.htm)

According to table (2) the category which has the second rank of the frequency of occurrence is the one allocated to military terminology as in the following example extract:

Iraq's need for air power is clear. Its air force has consisted of several Cessna planes that carry American-supplied Hellfire missiles and an assortment of American and Russian-supplied helicopters, which the Iraqi military used during its recent fight with ISIS in Tikrit.

The United States has sold Iraq F-16 warplane .... [T] he American contractors ... have supported the program were evacuated from the Balad air base during the ISIS offensive. Iraq recently announced that it was also buying Su-25s from Russia, but those aircraft are not yet believed to be in operation. Iran's provision of the $\mathbf{S u - 2 5 s}$ follows its decision to send a fleet of Ababil surveillance drones, an intelligence unit to intercept communications and advisers.

Like the Iranian drone and intelligence units, the aircrafts are based at the Rasheed air base in Baghdad. Similar to the American A-10 aircraft, the Su-25 is designed for ground attacks. It is equipped with a 30-millimeter cannon and armed with rockets and bombs, and it could be effective against ISIS convoys and concentrations of ISIS fighters....

(http://www.nytimes.com/2014/07/09/world/middleeast/iransends-3-attack-planes-to-iraqi-government.html? $r=0$ )

Such terms have mostly been used for particular purposes like talking about the military equipment necessary for facing attacks, the terrorists' operations in the Iraqi provinces and the territories of Iraq, and 
reporting the results of a fight between the Iraqi forces and a particular antigovernment group of militants.

Looking back at table (2) the category which has the third rank of occurrence is the one of the geographical terminology which the reporters have relied on to inform the readers of the places in Iraq in which the security events have taken place. Such terminology is represented by names of provinces, regions of parts of provinces, territories that separate Iraq from the other neighboring states, and certain government main institutes. Consider the following extract which contains examples of geographical terminology:

Iraq's million-strong army, trained and equipped by the United States, largely evaporated in the north after Sunni fighters led by the Islamic State in Iraq and the Levant launched their assault with the capture of the north's biggest city Mosul on June 10.

But in recent days, government forces have been fighting back, relying on elite commandos flown in by helicopter to defend the country's biggest oil refinery at Baiji.

A successful operation to recapture territory inside Tikrit would deliver the most serious blow yet against an insurgency which for most of the past two weeks has seemed all but unstoppable in the Sunni heartland north and west of Baghdad.

(http://www.reuters.com/article/2014/06/26/us-iraq-securityidUSKBNOF10TF20140626)

The fourth rank of the frequency of occurrence (in the categories of the sixth technique) goes to the national community titles. In Iraq, there are three main nationalities; the Arabs, Kurds and Turkmen. The word Arabs has been repeated four times; in three of them, the word has come in association with the words Sunni, Shiite, majority, and territories. The word Kurds/Kurdish has been repeated twelve times; in six of them, the 
word has come in association with the words Sunni, minority, ethnic, north, and territories. The word Turkmen has not been mentioned in the articles analyzed. The following extracts are examples for such use:

Sunni, Kurdish and rival Shi'ite groups have demanded he leave office... although close allies say he has no plan to step aside.

(http://www.reuters.com/article/2014/06/26/ MALIKI UNDER PRESSUREUSKBNOF10TF20140626)

The central government in the capital Baghdad is now dominated by the Shiite Arab majority ... Sunni Arabs ....

Iraq's Kurdish minority, on the other hand, enjoys a strong autonomy in the north of the country.... The Kurds are at odds with the central government over the division of oil profits and the final status of mixed Arab-Kurdish territories.

\section{http://middleeast.about.com/od/iral/tp/Current-Situation-In-} Iraq.htm

As far as the religious vocabulary items are concerned, they have occurred two times represented by two words: Muslims and Islamists. Such terms haven't had a significant frequency in NASSIs analyzed and the language of reporters hasn't shown any tendency for their use.

2. Going back to table (1), it is the second technique of IN (namely indirect quotation) which has got the second order according to the frequency of occurrence (66 times) among the other techniques in comparison with the first technique (namely direct quotation) which has come in the third order (23 times). It is quite natural for both direct and indirect quotation to be used in news discourse since the prime purpose of such discourse is to report, whether directly or indirectly, pieces of news, statements, opinions, events talked about by witnesses, people in power, etc.

A very careful reading of the news items in NASSIs represented by the two techniques of IN mentioned above shows clearly that the reporters are topic sensitive in how they construct their reports. They understand 
how to use IN references to support their news reports. The direct and indirect quotation techniques have been used in the reports that can be exclusively classified under three topics:

a) Reporting major security events that denote serious security deterioration and/or include a lot of casualties. The following extracts are examples of direct and indirect reports bearing such a topic:

"All parties to the conflict, ... have the legal obligation and moral responsibility to do everything they can to avoid and prevent violence against civilians and ensure that their humanitarian needs are addressed," the statement said. "The secretary-general is deeply troubled by persistent reports of violations of human rights and international humanitarian law taking place in Iraq, including summary execution of captured soldiers and detainees, indiscriminate shelling of civilian areas, and the abduction and murder of members of ethnic ...."

(http://www.shanghaidaily.com/article/article_xinhua.aspx?id $=227095$ )

At least 50 bodies, blindfolded, bound and shot, were found Wednesday in Babil Province, a region that lies directly south of Baghdad, according to the chairman of the provincial council.

(http://www.nytimes.com/2014/07/10/world/middleeast/inapparent-mass-killing-bodies-found-in-region-south-of)

b) Reporting details and numbers related to a security state. Consider the following example extracts:

Ahmed al-Jubbour, professor at the university's college of agriculture, described fighting in the colleges of agriculture and sports education after three helicopters arrived. 
"I saw one of the helicopters land opposite the university with my own eyes and I saw clashes between dozens of militants and government forces," he said.

(http://www.reuters.com/article/2014/06/26/us-iraq-securityidUSKBNOF10TF20140626)

An official at Jordan's Agriculture Ministry, for instance, said that 140 tons of peaches had crossed into Iraq, indicating that the militants may want to use the crossing not to threaten Jordan, but to secure its claims of statehood, by allowing goods into its territories.

(http://www.nytimes.com/2014/06/24/world/middleeast/sunnimilitants-seize-crossing-on-iraq-jordan-border.html)

c) Reporting statements of people of authority, spokesmen, officials and ordinary citizens from the heart of the event as shown in the following extracts:

UN Secretary-General Ban Ki- moon on Sunday voiced his deep concern at "the deepening crisis in Iraq and the rising number of civilian deaths and injuries," calling for an immediate end to the "persecution of civilians based on their religion or ethnic background."

"The secretary-general expresses his grave concern at the deepening crisis in Iraq ... with over one million Iraqis having fled their homes due to the fighting," said a statement issued here by Ban's spokesman. "The secretary-general calls on all parties to the conflict ensure that persecution of civilians based on ...."

(http://www.shanghaidaily.com/article/article xinhua.aspx? $i d=227095$ )

"We're tired of these daily sit-ins and demonstrations - every day we have a new drama," said a Falluja food store owner, one of the few to open his doors to customers. "I just want to earn a living." 
(http://www.reuters.com/article/2013/04/22/us-iraq-politicsprotests-idUSBRE93L0T020130422)

On Monday afternoon, a policeman who works at the crossing and who spoke on the condition of anonymity said that several members of the Iraqi security forces were still holed up in one of the buildings .... Local tribal leaders were trying to negotiate their passage to safety, the policeman said.

(http://www.nytimes.com/2014/06/24/world/middleeast/sunnimilitants-seize-crossing-on-iraq-jordan-border.html)

3. The third technique (mentioning a person, document or statements by relying on general beliefs about the original text without specifying details of meaning) has taken the fourth rank of occurrence (16 times according to table (1)). A careful examination of the instances of this technique in the NASSIs reveals that the use of this way of IN has been specified for three topics as follows:

a) Expressing statements related to the general state in Iraq. These statements are beyond controversy according to the readers' awareness of them and according to their truthfulness. Consider the following example extract:

Prime Minister Nuri al-Maliki, whose Shi'ite-led State of Law coalition won the most seats in the April election but needs allies to form a cabinet, is under strong pressure from the United States and other countries .... (http://www.reuters.com/article/2014/06/26/ MALIKI UNDER PRESSUREUSKBNOF10TF20140626)

b) Mentioning a particular incident as part of a report without giving details of that report. For example:

The elements of the crisis caused by the advances of the armed group ... must be addressed militarily, Nickolay Mladenov, the secretary-general's special representative in Iraq, said as he briefed journalists here last week via video from Baghdad, the Iraqi capital.... 
(http://www.shanghaidaily.com/article/article_xinhua.aspx?id $=227095$ )

c) Denying that a particular report has taken place. An example is: Government spokesmen did not respond to requests for comment and by evening the assault was still not being reported on state media.

(http://www.reuters.com/article/2014/06/26/us-iraq-securityidUSKBNOF10TF20140626)

Accordingly, along with direct and indirect quotation, the use of this technique seems to be topic dependent.

4. The forth technique of IN (commenting on or evaluating a statement, text, or otherwise invoked voice) has been put in the fifth rank according to table (1) occurring 9 times only throughout the 12 NASSIs analyzed. In the nine times, the reporters have never put themselves in the position of evaluators. Instead, they have merely given comments about particular reports or issues related to the general security situation in Iraq. An example is:

The Iraqis' insistence that all of the planes are Iraqi-owned is significant because Iraq would be violating international sanctions .... But the Iraqis' insistence that they alone are operating the planes leaves unclear how the aircraft, which have not been part of the Iraqi military's inventory for two decades, were flown to Iraq and are currently being maintained.

(http://www.nytimes.com/2014/07/09/world/middleeast/iransends-3-attack-planes-to-iraqi-government.html?_r=0)

5. The last technique to talk about in the analysis is the fifth one (namely using recognizable phrasing, terminology associated with specific people or groups of people or particular documents) because it has had the lowest frequency of occurrence. Throughout the 12 NASSIs analyzed, it has occurred once only in article No. 6 according to table (1) represented by the old-fashioned idiom kith and kin as follows: 
"The Red Crescent had spoken to the people there and written to us saying that they are safe," Ms Swaraj said.

She also met the families of those who have been kidnapped and assured them that the government was taking all steps for the safety and evacuation of their kith and kin.

(http://www.ndtv.com/article/india/iraq-crisis-sushma-swarajholds-high-level-meeting-three-air-india-planes-on-standbyfor-evacuation-550006)

According to the extract above, the idiom has been used to refer to the relatives and friends of some Indian families. Those friends and relatives are supposed to have been kidnapped or working in Iraq and haven't been evacuated yet after the escalation of the security situation.

\section{Conclusions}

1. News articles are usually interaction between reporters and readers. According to the analysis, there has been a rather high frequency of occurrence of IN cases in the NASS; 246 in 12 articles. This fact leads to the conclusion that these news articles try to set up intertextual relation between news items and readers. As we know, one of the purposes of a news article is to persuade the readers into believing the truth of the news items. Thus, news articles must have a believing power which can arouse people's interest in tending to accept the news items as truthful. To achieve this, news articles should have attention value that impresses the readers and makes them accept the news items as truthful. News articles often create IN which, in its turn, encourages readers to ponder and make association with their previous knowledge. This process raises the readers' feeling of familiarity facilitating their belief of truthfulness.

2. According to the analysis, there is a heavy use of the words Sunni and Shiite which are related to the technique of using language and forms that seem to echo certain ways of communication, discussions among other people, and types of documents; that is technique number six. This heavy use of these words reflects the view point of the foreign world in general and the foreign media in particular. They look at the Iraqi community as a divided community that has been worn out by the sectarian conflict which 
represents the main reason for the deterioration of the security situation in Iraq. This could be true for some extent, but it is important for the world to know that the religious communities represent the trump card that the destructive forces (whoever they are) have used to create the sectarian conflict which, in its turn, represents an effective way to keep Iraq indulged in an endless war and security deterioration. This war is clearly being supported by the foreign media through the use of detestable sectarian language devices on the top of which is the use of the words Sunni and Shiite.

The category of the second rank, in relation to the frequency of occurrence of IN modes related to technique number six, is the one allocated to military terminology. Although this category hasn't had the highest frequency of occurrence, without this category of terms the NASSIs would have lost much of its informing power. This is related to the fact that the pieces of news are related to the security situation which, in many of its facets, is in turmoil and taking place in real military fields. Iraq has been exposed to different terrorist attacks not only in the populated civilian areas but on the territories among its provinces and those which separate it from the other neighboring states. Mostly, the territory areas are at the responsibility of the military forces giving the security operations there a military nature and, thus, leading the news text to be loaded with military terms.

In many instances, there have been clashes between what the NASSIs call militants or insurgents and the Iraqi forces in the form of street war inside civilian areas. Describing these clashes has created the need for such an almost heavy use of military terms.

The category of vocabulary that has the third rank, in relation to technique number six, is the geographical terminology. This seems logical since the reporters need to use such terminology to specify the locations of the security scenes which they inform the readers about.

The two words which name two of the nationalities in Iraq; namely Arabs and Kurds, have mostly occurred in association with words like Sunni, Shiite, territories, minority, majority, ethnic, and north. Pondering these words carefully, one immediately realizes that they suggest a sort of 
discrimination. This supports the previous claim that the NASSIs, as part of the foreign media, try to fuel the sectarian ethnic conflict in Iraq. The use of this sort of vocabulary enhances the world's view towards Iraq that is subject to the initial split along ethnic lines.

Generally speaking, the frequent reoccurrence of the words Sunni, Shiite, Arabs and Kurds has cleverly and implicitly served the reporters, together with the foreign news media as whole, to express their position according to the conflict in Iraq. They haven't given their opinion explicitly. Instead, they have interpreted the news subjectively through the heavy use of the words mentioned above.

3. The use of the direct and indirect quotation techniques in NASSIs is topic sensitive; the reporters have used the two techniques with particular topics and situations which have already been mentioned in the analysis. The frequency of occurrence of the two techniques in general is 89 (23 for the direct quotation and 66 for the indirect quotation) in the 12 NASSIs analyzed. This number of occurrence is a considerable one which leads us to two concluding points. The first is that the reporters try to attract the readers' attention since the use of direct and indirect quotations are more lively and expressive ways of IN. The second is to gain the readers' confidence by trying to make the news items more objective.

However, the reporters have relied more on the indirect quotation technique which has been used 66 times in the 12 articles analyzed in comparison with the direct quotation technique which has been used 23 times. Resorting mostly to this sort of indirect language, the reporters seem to try to sound more persuasive to make the readers perceive the given information as a part of news report and therefore the reporters gain their confidence.

4. When resorting to the IN technique of mentioning a person, document or statements by relying on general beliefs, the reporter seems to be topic sensitive; as is the case with direct and indirect quotation. They have used this technique for three particular topics which have already been mentioned in the analysis. The use of this technique has the effect of cognitive enlightment on the reader which contributes to his general 
comprehension of the news items within which, the piece of information has been given using the technique under discussion.

5. The nine instances of IN in which the reporters have given their own comments and opinions about a certain issue leads to the conclusion that the reporters seem to shift between their roles as presenters of news from which they always attempt to keep a distance, and as commentators on news in which they form their opinions or comments when they think these opinions and comments are in line with the public knowledge. The reporters have employed the readers' common knowledge as explicit intertextual sources to illustrate their comments and opinions. Otherwise, the reporters are highly conscious of their sources of IN and avoid revealing their personal views on the issues concerned.

6. According to the analysis, the fifth technique (namely using recognizable phrasing, terminology associated with specific people or groups of people or particular documents) has got the lowest frequency of occurrence. This fact leads to the conclusion that the reporters do their best to make their articles unique and avoid the use of any recognizable language which may echo specific people or groups of people or particular documents. They want their articles to be clear from any phrasing or terminology that the readers would definitely recognize as pieces of language taken from easily recognizable sources. As a result, the text would, somehow, lose much of its uniqueness and the reader would lose his interest in the news items even though new and haven't been tackled before. 


\section{References:}

Allen, G. (2000) Intertextuality. London: Routledge.

(2003) Roland Barthes. London: Routledge.

Bazerman, C. (2004) "Intertextuality: How Texts Rely on Other Texts. In Bazerman, C. and Prior, P. (eds.). What Writing Does and How It Does It: An Introduction to Analyzing Texts and Textual Practices. Mahwah, NJ: Lawrence Erlbaum Associates, pp. 83-96.

Bhatia, V. (2010) "Interdiscursivity in Professional Communication" In Discourse and Communication, Vol. 4, No. 1, pp. 32-50.

Cook, G. (2001). The discourse of advertising. New York: Rutledge.

Fairclough, N. (1992) Discourse and Social Change. Cambridge: Polity Press.

Goddard, A. (2007). The language of advertising: written texts. New York: Routledge

Liu, J. and Le, T. (2013) "Intertextual Techniques in Advertisements" In International Journal of Innovative Interdisciplinary Research, Vol. 2, No. 1, pp. 11-19.

Montgomery, M.; Durant, A.; Fabb, N.; Furniss, T. and Mills, S. (2007) Ways of Reading .London: Routledge.

Panigrahi, D. (2013) "Intertextuality in Advertising” In Language in India, Vol. 13, No. 9 , pp. 251-264.

Pulungan, A.H. (2010) "Intertextuality in Indonesian Newspaper Opinion Articles on Education: Its Types, Functions, and Discursive Practice” In TEFLIN Journal, Vol. 21, No. 2, pp. 137-152.

Xin, B. (2000) Intertextuality from a Critical Perspective. Suzhou: Suzhou University Press.

http://www.reuters.com/article/2014/06/26/us-iraq-security-idUSKBN0F10TF20140626

http://www.shanghaidaily.com/article/article_xinhua.aspx?id=227095

http://www.cnbc.com/id/101743284

http://www.ndtv.com/article/india/iraq-crisis-sushma-swaraj-holds-high-level-meetingthree-air-india-planes-on-standby-for-evacuation-550006

http://www.nytimes.com/2014/06/24/world/middleeast/sunni-militants-seize-crossingon-iraq-jordan-border.html

http://www.reuters.com/article/2014/06/26/ MALIKI UNDER PRESSURE

USKBNOF10TF20140626

http://www.nytimes.com/2014/07/09/world/middleeast/iran-sends-3-attack-planes-toiraqi-government.html? $\mathrm{r}=0$ 
http://www.nytimes.com/2014/07/10/world/middleeast/in-apparent-mass-killing-bodiesfound-in-region-south-of

http://middleeast.about.com/od/ira1/tp/Current-Situation-In-Iraq.htm

http://middleeast.about.com/od/ira1/tp/ Sectarian Tension.htm

http://middleeast.about.com/od/ira1/tp Power in Iraq /.htm

http://www.reuters.com/article/2013/04/22/us-iraq-politics-protestsidUSBRE93L0T020130422

http://www.online-literature.com

\section{List of Abbreviations}

Intertextuality

IN

News Articles on the Security

NASSI

Situation in Iraq

\section{List of Tables}

\section{Title of Table}

Page No.

Table (1): The Frequency of Occurrence

of Each Technique in the Twelve

Articles

Table (2): The Frequency of Occurrence

of Each Vocabulary Category 


\section{التناص في مقالات الأخبار التي تتناول الوضع الأمني في العراق \\ مدرس: هدى هادي خليل}

جامعة بغداد/ كلية التربية للبنات/ قسم اللغة الانكليزية

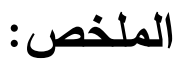

يعدُ التتاص نوعا من العلاقات التي نربط النصوص مع بعضها البعض فهو العلاقة التي يقوم من خلالها كل نص بالإثارة الى نص اخر • اكتسبت المعلومات في أيامنا هذه صفة عالمية بسبب التكنلوجيا الحديثة التي جعلت من وسائل الاعلام (التي تعد من أكثر الوسائل تأثثراً) ذات تأثثير ليس على مستوى المجتمع بصورة عامة بل على مستوى الفرد بصورة خاصة حيث تؤثز المعلومة وكيفية انتقالها على تقكير الناس وآرائهم. عند كتابة الاخبار يواجه الصحفيون مشكلة تكمن في رغبتهم بأن يكونوا مبدعين ومنفردين ويشيرون في الوقت ذاته الى حقائق ثابتة

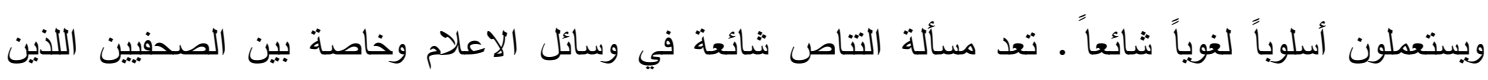
يعتبرونها فاعلة في تحقيق أهدافهم لذلك يهدف البحث الحالي الى تقصي الاهداف التي تدفع الصحفيين اللذين يكتبون مقالات عن الوضع الامني في العراق الى اللجوء للتناص. يعتمد ذلك على تحليل دقيق لتقنيات التتاص التي يعتمد عليها الصحفيون في هذا النوع من المقالات. لقد شهد الوضع الأمني في العراق فترات عديدة من التصعيد وبضمنها تلك الواقعة بين نبسان وحزيران من عام ؟ ا ـr ـ الهدف هنا هو معرفة الكيفية التي يوظف بها الصحفيون التتاص كي يخبروا العالم عن الوضع الأمني في العراق في واحدة من فتراته الحرجة. لذلك تم تحميل أثتا عشرة مقالة من هذا النوع من شبكة الأنترنت وتم تحلبلها بدقة. تم أجراء التحليل اعتمادا على نموذج بأزمان

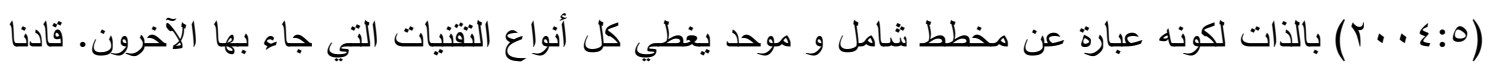
التحليل الدقيق الى عدد من النتائج اهمها الاستخدام المكثق للتناص من الصحفيين الذين قاموا بتوظيف جميع تقنيات التتاص مع التركيز على تقنيات معينة من اجل تحقيق اهداف معينة في النص. 